学術論文

\title{
磁性金属板判別のための空心円形コイルのサイズ検討
}

\section{Consideration of air-core coil size for magnetic metal plate identification}

藤田 竜司 ${ }^{* 1}$ (学生員), 木村 藤一郎 ${ }^{* 1}$ (学生員), 二俣 昌樹 ${ }^{* 1}$, 田代 晋久 ${ }^{* 1}$ (正員),

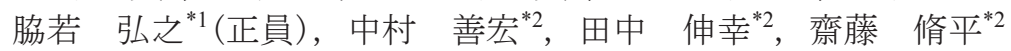

Ryuji FUJITA (Stu.Mem.), Toichiro KIMURA (Stu.Mem.), Masaki FUTAMATA, Kunihisa TASHIRO (Mem.), Hiroyuki WAKIWAKA (Mem.), Yoshihiro NAKAMURA, Nobuyuki TANAKA, Syuhei SAITO

An eddy current method is a method for discriminating metals nondestructive and noncontact. It is very important to know the changes in the frequency profile of sensor coil inductance. If an air-core coil is placed to face an iron plate, the changes contain both the conductivity and permeability information. In order to find a suitable coil size, the same values of in inductance are designed for four coils which have different diameter to generate same magnetic flux at a constant current. The frequency profiles are measured with a conventional impedance analyzer, as a function of distance between the coil and metal plate. The measured values are as same as $200 \mu \mathrm{H}$ for four coils until a few hundred Hz. When the coils are placed to face the metal, a decrease in lift off produces an increase in inductance at low frequency, and a decrease in inductance at high frequency. There is a cross frequency at which the measured value is as same as inductance of coil only. It is found that it seems to be defined by the coil diameter, not defined by the liftoff. Introducing normalized parameters, other useful considerations are also noted.

Keywords: metal discrimination, eddy current, inductance, frequency characteristics.

(2017 年 10 月 26 日受付, 2018 年 1 月 24 日再受付, 2018 年 2 月 28 日再々受付)

\section{1 緒言}

対象物である金属を非破壊，非接触で判別する方法 として渦電流法[1]が挙げられる。検出方法として検出 されたパラメータを基準值と比較することによって金 属判別が行われる。センサ部がコイルであるため, X 線分光分析法[1]などの判別方法に比べ小型かつ低コ ストで構成することが可能である。

渦電流法は，非破壊探傷法などに多く利用されてい るが，金属の材質のむらやわずかな違いを検出し判別 できる判別センサとしての高性能化のニーズも大きい。 我々は磁性, 非磁性問わず複数の金属を判別する金属 判別センサの金属材質検出性能の向上を目的に研究を 行っている。渦電流法による金属判別センサに求めら れるのは対象物である金属を非破壊, 非接触で判別を 行い，低コストかつ小型のセンサである。小型かつ精 度が高いセンサを製作するためには対象物である金属 板のサイズ及びリフトオフ(コイルと金属板の距離)に 対して最適なコイルサイズの検討を行う必要がある。 先行研究ではコイル形状の違いで金属板に発生する渦 電流の表皮深さについて有限要素法を用いた解析が行

連絡先：田代 晋久, $\bar{\top} 380-8553$ 長野県長野市若里 4-17-1, 信州大学工学部 田代研究室, e-mail: tashiro@shinshu-u.ac.jp ${ }^{* 1}$ 信州大学 ${ }^{*}$ 富士電機株式会社
われている。結果としてコイル高さ及びリフトオフよ りもコイルの平均半径の方が渦電流の表皮深さに影響 を与えていることを報告している[2]。

前報ではコイルインダクタンス $L(\mathrm{H})$ 及びサイズが 異なる 2 種類のコア付コイルを用いた金属板判別法の 検討を一次微分波形の最大值の変化率で行った。その 結果，コイルサイズが大きい方が一次微分波形の最大 值の変化率が増大したため優位性があると考察した。 しかし $L$ が一定ではなく, 且つコアを用いているため 最適なコイルサイズを明確には示せていない[3]。

本報告では磁性金属板判別の最適なコイルサイズ の検討を行った。磁性金属板に着目した理由として, 非磁性金属板に関しては金属板とほぼ等しいコイルサ イズが周波数によらず適していることを前報[4]で明 らかにしたからである。 $L$ 及び金属板に対向する面の 寸法比が一定となるように 4 種類の空心円形コイルを 製作した。製作したコイルの $L$ の周波数特性を測定し, 金属板を対向させたことによる $L$ の変化に対して，2 種類のパラメータで正規化を行った。そして，金属判 別の最適なコイルサイズが励磁周波数で変化するか評 価するために $1 \mathrm{kHz}$ 及び $200 \mathrm{kHz}$ に着目し，最適なコ イルサイズの検討を行ったため報告する。 


\section{2 金属板の判別原理}

渦電流法はコイルに金属板を対向させた際，コイル と鎖交する磁束数に変化が生じ，インピーダンスが変 化する。この変化を基準值と比較して判別を行う。発 生する渦電流は導電率 $\sigma(\mathrm{S} / \mathrm{m})$ によって異なり, 金属に よってコイルインピーダンスの変化には差異が生じる。

Fig. 1 に前報[3]で測定した外径が約 $18 \mathrm{~mm} の \Phi 18$ ב イルのコイルインダクタンス $L(\mathrm{H})$ の周波数特性を示 す。Table 1 に $\Phi 18$ コイルの仕様, Fig. 2 にフェライト コアの寸法を示す。また, Table 2 に測定条件, Table 3 に対向させた金属の導電率を示寸 [5]。Fig. 1 より, 非 磁性体であるアルミニウムの金属板を対向させた場合 は測定周波数の全てで $L$ はコイルのみに比べ減少する 傾向を示した。次に磁性体である鉄の金属板を対向さ せた場合，低周波帯では $L$ はコイルのみに比べ増加し た。高周波帯では $L$ はコイルのみに比べ減少する傾向 を示した。これは低周波帯では磁性体を対向させたこ とにより磁束が収束されることで $L$ が増加した。そし て, 周波数が増加するに従い渦電流の影響が増大した ため, $L$ が減少したと言える。以上より, 磁性か非磁 性の金属板を対向させるかによって $L$ の変化が異なる。

Fig. 1 より, Fe と $\mathrm{Al}$ で曲線の傾向が異なる結果とな った。傾向が異なる要因として渦電流の影響が考えら れる。周波数の変化に対して $L$ の変化に影響を与える 要因は渦電流であり, 導電率 $\sigma(\mathrm{S} / \mathrm{m})$ の増加に従い渦電 流の影響は増す。Table 3 より $\sigma$ は $\mathrm{Al}$ の方が $\mathrm{Fe}$ に比べ 約 3.8 倍大きい。そのため周波数の変化に対して $\mathrm{Fe}$ と $\mathrm{Al}$ の $L$ 変化の傾向が異なる結果になったと考えられ る。またコイルのみの場合, $1000 \mathrm{kHz}$ 付近になると $L$ が増加した。これは用いた $\Phi 18$ コイルの自己共振周波 数が約 $2.4 \mathrm{MHz}$ であることを確認しており，コイルの 自己共振の影響で $L$ が増加したためである。

コイルのみに対する金属板対向時の $L$ の変化率 $\varepsilon_{\mathrm{L}}(\%)$ で金属判別を行う場合， $\varepsilon$ L が大きいコイルほど判別し 易いため，金属判別に適していると考えられる。Fig. 1 より, 対向させる金属板の種類によって $\varepsilon_{\mathrm{L}}$ が異なるた め, 最適なコイルサイズと周波数がそれぞれ存在する と言える。前報[3]では $L$ が一定ではなく, サイズが異 なる 2 種類のコア付コイルを用いて金属判別の検討を 行った。その結果，コイルサイズが大きい方に優位性 があると考察した。しかし， $L$ が一定ではなく且つコ アを用いているため最適なコイルサイズを明確には示 せていない。

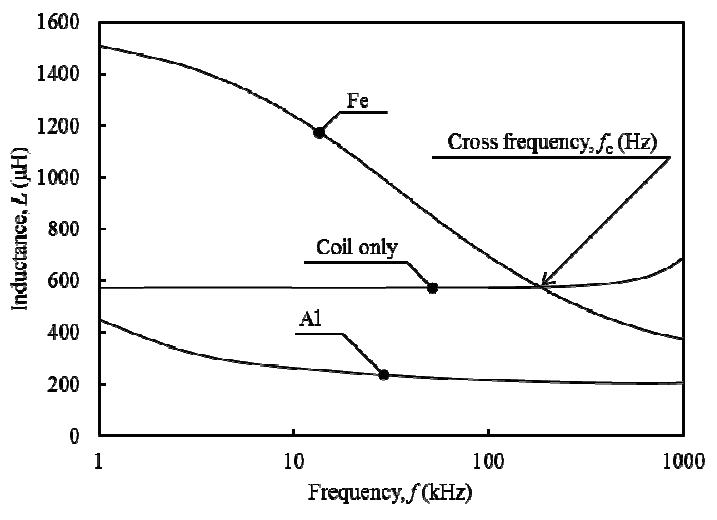

Fig. 1 Measured inductance as a function of frequency. ( $\Phi 18$ coil) [3]

Table 1 Specifications of the $\Phi 18$ coil.[3]

\begin{tabular}{|c|c|}
\hline Items & Contents \\
\hline Outer diameter, $a_{\mathrm{o}}(\mathrm{mm})$ & 15.8 \\
\hline Inner diameter, $a_{\mathrm{i}}(\mathrm{mm})$ & 4 \\
\hline Height, $h(\mathrm{~mm})$ & 0.78 \\
\hline Number of turns, $N($ turn $)$ & 185 \\
\hline Wire diameter, $\varphi(\mathrm{mm})$ & 0.14 \\
\hline Inductance, $L(\mu \mathrm{H})$ & 572 \\
\hline Resistance, $R_{\mathrm{L}}(\Omega)$ & 6.49 \\
\hline
\end{tabular}

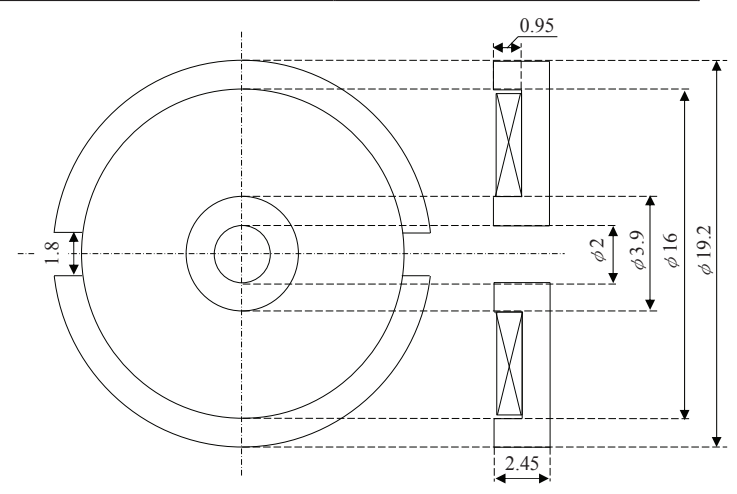

Fig. 2 Dimensions of the ferrite core.

(Unit : mm) [3]

Table 2 Measurement condition.

\begin{tabular}{|c|c|}
\hline Items & Contents \\
\hline Measuring equipment & $\begin{array}{c}\text { Impedance analyzer } \\
\text { (Agilent 4294A) }\end{array}$ \\
\hline Applied current, $I_{\text {in }}(\mathrm{mA})$ & 20 \\
\hline Measurement frequency, $f(\mathrm{kHz})$ & $1 \sim 1000$ \\
\hline Measurement points & 801 \\
\hline Average & 10 \\
\hline Lift off, $z(\mathrm{~mm})$ & 0.5 \\
\hline
\end{tabular}

Table 3 Conductivity of the metal.[5]

\begin{tabular}{|c|c|}
\hline Metal & Conductivity, $\sigma(\mathrm{S} / \mathrm{m})$ \\
\hline $\mathrm{Al}$ & $3.77 \times 10^{7}$ \\
\hline $\mathrm{Fe}$ & $1.00 \times 10^{7}$ \\
\hline
\end{tabular}


そこで本報告では $L$ が一定となるように 4 種類の空 心円形コイルを製作し，最適なコイルサイズの検討を 行った。著者らは本報告と同様の測定条件で非磁性金 属板(Al)判別のための空心円形コイルのサイズ検討を 報告している。その結果, 金属板とほぼ等しいサイズ のコイルが周波数によらず適していることを今回明ら かにした[4]。本報告では磁性金属板に着目し，最適な コイルサイズの検討を行った。前報[4]と同様に正規化 を行うことで金属板の寸法比が変化しても最適なコイ ルサイズを容易に提案できるため，正規化して評価を 行った。また，Fig. 1 に示すように磁性金属板を対向 させた場合は非磁性金属板では見られない $L$ の差異が 無くなる周波数 $f_{\mathrm{c}}(\mathrm{Hz})$ が存在するため, $f_{\mathrm{c}}$ にも着目し て評価した。

\section{3 コイル直径とインダクタンスの周波数特性}

\section{1 実験方法}

Fig. 3 に空心円形コイルのコイルインダクタンス $L$ $(\mathrm{H})$ の周波数特性の測定外観図を示す。インピーダンス アナライザ (Agilent 社, 4294A)を用いて空心円形コイ ルに鉄の金属板を対向させた際の $L$ の測定を行った。 入力電流 $20 \mathrm{~mA}$, 加算平均 3 , 測定周波数 $f=1 \mathrm{k} \sim 1000$ $\mathrm{k} \mathrm{Hz}$ の範囲で測定点 801 点の条件の下，コイルに鉄の 金属板を対向させた際の $L$ の変化を測定した。また, Fig. 4 にコイルと金属板の対向位置を示寸。Fig. 4より， 金属板の中心にコイルを対向させ，リフトオフ $z(\mathrm{~m})$ は $z=5 \sim 15 \mathrm{~mm}$ 設けた。 $z$ を変化させた理由は $\mathrm{z}$ の変 化に対して磁性金属板判別の最適なコイルサイズが変 化するのか評価するためである。また，金属板の寸法 は $100 \mathrm{~mm} \times 100 \mathrm{~mm} \times 1.5 \mathrm{~mm}$ である。

本報告では $L$ が $200 \mu \mathrm{H}$ 一定でサイズが異なる 4 種 類の空心円形コイルを用いた。Table 4 に本報告で使用 したコイルの仕様，Fig. 5 にコイルの外観図を示す。 Fig. 5 の図中に示したのはコイルの平均直径 $D(\mathrm{~m})$ であ る。製作したコイルの特徵として，判別対象の金属板 の幅 $W(\mathrm{~m})$ が $100 \mathrm{~mm}$ に対し, $D$ が約 $100 \mathrm{~mm}$ の空心円 形コイル(Coill)を製作した。そして Coill に対して Coil2, Coil3, Coil4 の D 及びコイルの厚み $c(\mathrm{~m})$ が 1/2 倍，1/4 倍，1/8 倍となるように製作した。本報告では Coill ～Coil4 は全て $D<W$ となるように製作した。 $L$ の計算値は Lyle の近似式[6]を用いて求めた。

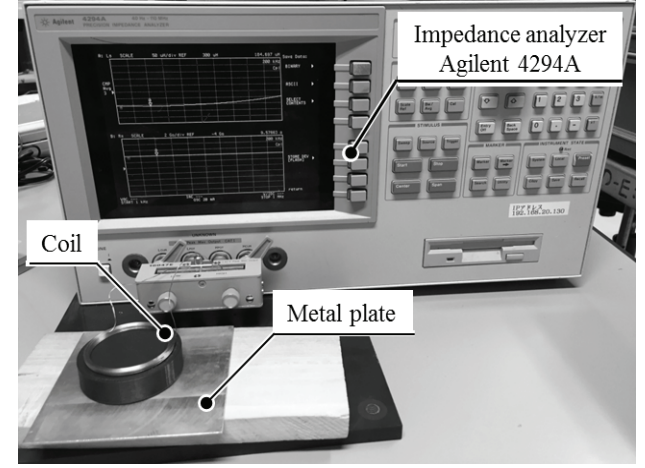

Fig. 3 Over view of measurement.

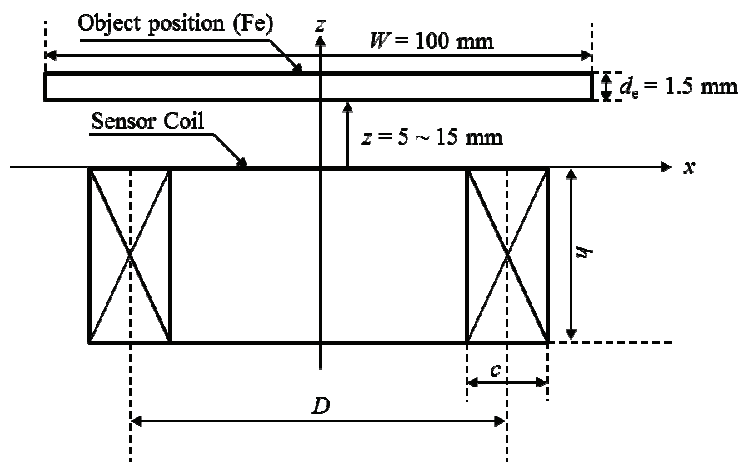

Fig. 4 Sensor coil and metal plate.

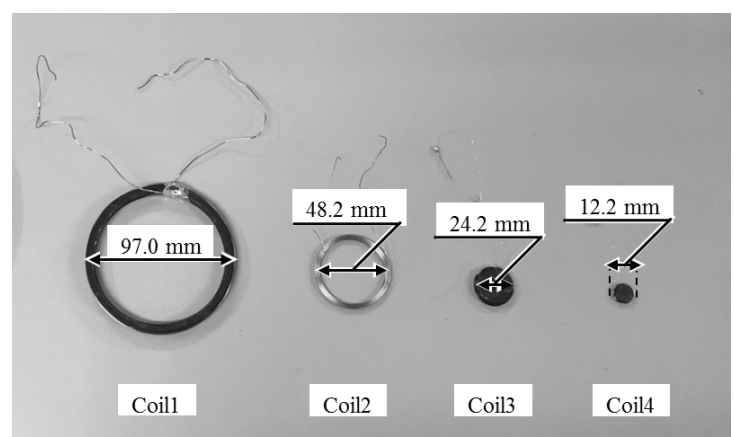

Fig. 5 Photo of four coils.

\section{2 実験結果}

Fig. 6 に周波数に対する $L$ の測定結果を示寸。Fig. 6 より Coil1 Coil4 のいずれも低周波帯では $L$ はコイル のみに比べ増加した。高周波帯では $L$ はコイルのみに 比心減少する傾向を示した。また本報告では $200 \%$ 以 上の $L$ の増加は得られなかった。しかし Fig. 1 より， 前報[3]のコア付コイルを用いた場合 $200 \%$ 以上の $L$ の 増加が得られた。コア付コイルは準閉磁路構造をして いる。反磁界が抑制され，見かけ上の透磁率が増加す ることで $L$ が増加した可能性がある。

次に $L$ の差異が無くなる周波数 $f_{\mathrm{c}}(\mathrm{Hz})$ に着目した。 Fig. 7 に平均直径 $D(\mathrm{~m})$ に対する $f_{\mathrm{c}}$ 特性を示す。Fig. 7 より, $D$ または $z$ が増加するに従い $f_{\mathrm{c}}$ は低くなる傾向 が得られた。これは $D$ または $z$ が増加するに従い，透 
磁率に対して導電率の影響が増大したため， $f_{\mathrm{c}}$ が低く

なったと考えられる。 $f_{\mathrm{c}}$ は非磁性金属板では現れない

傾向であり， $f_{\mathrm{c}}$ の有無だけで磁性か非磁性か判別する

ことが可能であると考えられる。

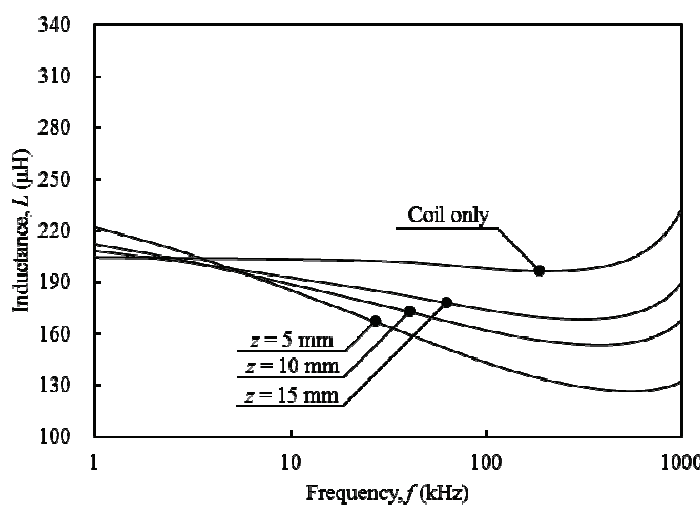

(a) Coil1

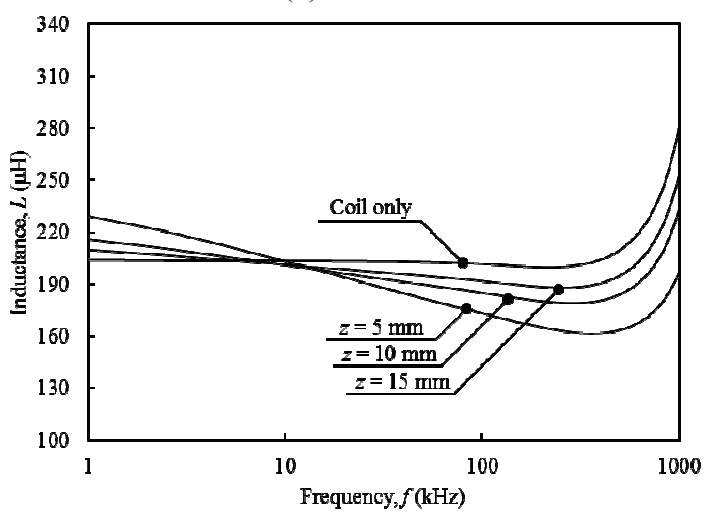

(b) Coil2

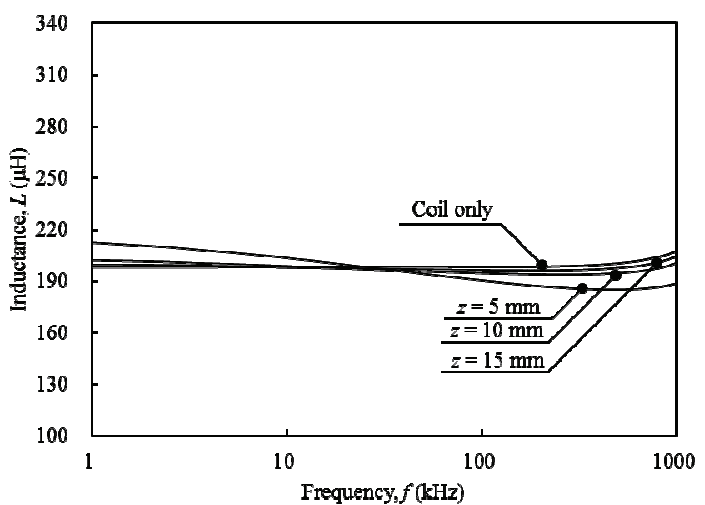

(c) Coil3

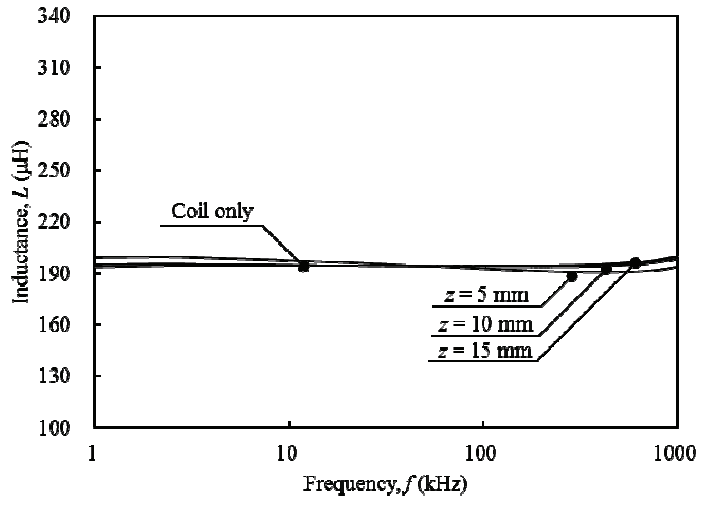

(d) Coil4

Fig. 6 Frequency characteristics of four coil inductance. (Measured)

Table 4 Specifications of sensor coils.

\begin{tabular}{|c|c|c|c|c|c|}
\hline \multirow{2}{*}{\multicolumn{2}{|c|}{ Items }} & \multicolumn{4}{|c|}{ Contents } \\
\hline & & Coill & Coil2 & Coil3 & Coil4 \\
\hline \multicolumn{2}{|c|}{ Mean diameter, $D(\mathrm{~mm})$} & 97.0 & 48.2 & 24.2 & 12.2 \\
\hline \multicolumn{2}{|c|}{ Height, $h(\mathrm{~mm})$} & 4 & 2 & 1 & 0.65 \\
\hline \multicolumn{2}{|c|}{ Thickness of coil, $c(\mathrm{~mm})$} & 4 & 2 & 1 & 0.5 \\
\hline \multicolumn{2}{|c|}{ Number of turns, $N$ (turn) } & 32 & 45 & 64 & 90 \\
\hline \multicolumn{2}{|c|}{ Wire diameter, $\varphi(\mathrm{mm})$} & 0.7 & 0.45 & 0.12 & 0.06 \\
\hline \multirow{3}{*}{$\begin{array}{c}\text { Inductance } \\
(f=200 \mathrm{kHz})\end{array}$} & Calculated, $L_{\mathrm{c}}(\mu \mathrm{H})$ & 211 & 206 & 211 & 209 \\
\hline & Measured, $L_{o}(\mu \mathrm{H})$ & 197 & 200 & 199 & 195 \\
\hline & Error, $\varepsilon_{\mathrm{e}}(\%)$ & -6.6 & -2.9 & -5.7 & -6.7 \\
\hline \multirow{3}{*}{ DC resistance } & Calculated, $R_{\mathrm{c}}(\Omega)$ & 0.45 & 0.94 & 8.26 & 20.4 \\
\hline & Measured, $R_{\mathrm{L}}(\Omega)$ & 0.41 & 0.72 & 7.28 & 25.6 \\
\hline & Error, $\varepsilon_{\mathrm{R}}(\%)$ & -8.9 & -23 & -12 & 25 \\
\hline
\end{tabular}




\section{4 正規化パラメータによる考察}

\section{1 正規化パラメータ}

コイルのみに対する鉄の金属板対向時のコイルイ ンダクタンス $L(\mathrm{H})$ の変化率 $\varepsilon_{\mathrm{L}}(\%)$ を最大にできるコイ ルサイズを見出すために $L_{\mathrm{m}} / L_{\mathrm{o}}$ に対し, 2 種類のパラメ 一タ (1) $z / D$, (2) $D / W$ で正規化した。ここで $L_{\mathrm{m}}(\mathrm{H})$ は鉄の 金属板対向時の $L, L_{\mathrm{o}}(\mathrm{H})$ はコイルのみの $L, z(\mathrm{~m})$ はリ フトオフ(コイルと金属板の距離), $D(\mathrm{~m})$ はコイルの平 均直径, $W(\mathrm{~m})$ は金属板の幅である。 $z / D, D / W$ で正規 化した理由を以下に示す。 $z / D$ で正規化した理由は $z$ またはDのどちらが $\varepsilon$ に影響を与えるのか評価を行い たいためである。金属判別性能を向上させるためには 金属板が $L$ に与える影響を増大させる必要がある。そ のため, $z$ または $D$ のどちらを変化させれば $\varepsilon$ 夯増大 するか調査する目的で正規化した。 $D / W$ で正規化した 理由は先ほども述べたように $\varepsilon_{\mathrm{L}}$ を最大にできるコイル サイズを見出すためである。また， $L_{\mathrm{m}} ， L_{\mathrm{o}}$ は $1 \mathrm{kHz}$ 及 び $200 \mathrm{kHz}$ の值を用いた。2 種類の周波数に着目した 理由として低周波帯または高㓮波帯のどちらに優位性 があるのか比較したかったためである。次節以降は正 規化して評価した結果について考察を行う。

\section{2 コイル平均直径とリフトオフ}

Fig. 8 に $z / D$ に対する $L_{\mathrm{m}} / L_{\mathrm{o}}$ 特性を示す。Fig. 8 より, $200 \mathrm{kHz}$ の場合 Coill Coil4 は非磁性金属板と同様に 1 つの曲線が得られた。1 kHzの場合 Coil2 Coil4 では 1 つの曲線が得られた。しかし, Coill は Coil2 Coil4 で得られた曲線には沿わなかった。この結果から，低 周波帯において Coil1 と Coil2 C Coil4 では金属板の渦 電流分布が異なる可能性が考えられる。

次にコイルサイズ及び $z$ のどちらがより $L$ に影響を 与えるのか評価した。Fig. 8(a)より，z/Dの值が等しい 点のコイルの $L_{\mathrm{m}} / L_{\mathrm{o}}$ を比較した場合, 全ての点でコイ ルサイズが小さい方が $L_{\mathrm{m}} / L_{\mathrm{o}}$ の変化が増加する傾向を 示した。次に Fig. 8(b)より, $z / D$ の值が等しい点のコイ ルの $L_{\mathrm{m}} / L_{\mathrm{o}}$ を比較した場合, 全ての点でコイルサイズ が大きい方が $L_{\mathrm{m}} / L_{\mathrm{o}}$ は減少する傾向を示した。従って, 導電率より透磁率の影響の方が支配的である $f=1 \mathrm{kHz}$ の場合はリフトオフ, 透磁率より導電率の影響の方が 支配的である $f=200 \mathrm{kHz}$ の場合はコイルサイズの方が $L$ に影響を与えると考えられる。

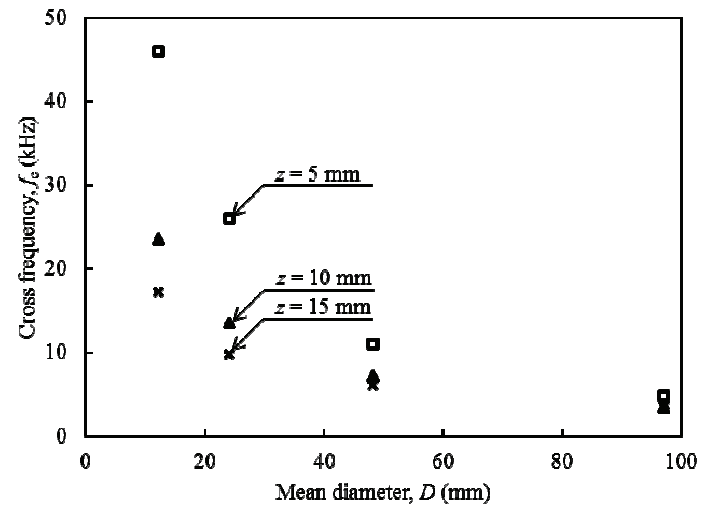

Fig. 7 Cross frequency as a function of mean diameter, as a parameter of lift off.

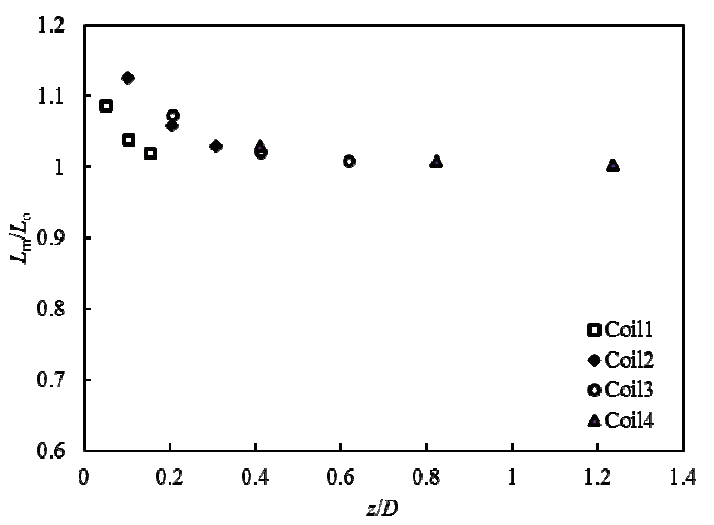

(a) $f=1 \mathrm{kHz}$

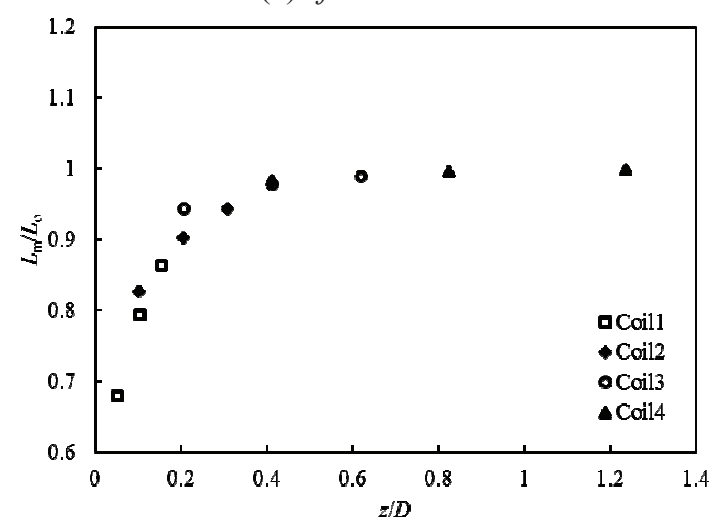

(b) $f=200 \mathrm{kHz}$

Fig. 8 Normalized inductance as a function of normalized distance, as a parameter of coil diameter. 4.3 コイル平均直径と金属板幅

Fig. 9 に $D / W$ に対する $L_{\mathrm{m}} / L_{\mathrm{o}}$ 特性を示す。Fig. 9(a)よ り $f=1 \mathrm{kHz}$ の場合, $D / W$ が約 $1 / 2$ の時 $L_{\mathrm{m}} / L_{\mathrm{o}}$ は最大值 を示した。次に Fig. 9(b)より $f=200 \mathrm{kHz}$ の場合, $D / W$ が増加するに従い $L_{\mathrm{m}} / L_{\mathrm{o}}$ は減少し, $D / W$ が約 1 の時 $L_{\mathrm{m}} / L_{\mathrm{o}}$ は最小值を示した。非磁性金属板の場合は周波数によ らず $D / W か ゙$ 約 1 の場合に $\varepsilon_{\mathrm{L}}$ の大きさが最大となった。 $1 \mathrm{kHz}$ の傾向が非磁性金属板と異なる要因として，低 
周波帯且つ磁性金属板を用いた場合は磁束の流れが異 なる可能性が考えられる。そして $\varepsilon \mathrm{L}$ が最大值となる $D / W$ が異なったため, 前節の Fig. 8(a)のような Coil1 と Coil2～Coil4 では明らかに異なる曲線が得られたと 考えられる。また, $200 \mathrm{kHz}$ の傾向は Table 3 に示すよ うに導電率はアルミニウムの方が鉄より約 3.8 倍大き いが，非磁性金属板と似た傾向が得られた。

عLが大きいほど，金属板を検出するのに適している と考えられる。鉄の金属板を検出する際，導電率より 透磁率の影響の方が支配的である $f=1 \mathrm{kHz}$ の場合 $D$ は $W$ の約 1/2 である Coil2 が適していると考えられる。 次に透磁率より導電率の影響の方が支配的である $f=$ $200 \mathrm{kHz}$ の場合 $D$ は $W$ とほぼ等しい Coill が適してい ると考えられる。以上より低周波带と高周波帯で $\varepsilon \mathrm{L}$ 最大にできるコイルサイズは異なることが言える。

\section{5 結言}

本報告では磁性金属板判別のための空心円形コイ ルのサイズ検討を行った。以下に得られた結果を示す。

(1) 磁性金属板対向時におけるコイルインダクタンス $L(\mathrm{H})$ の周波数特性を測定した。その結果, 非磁性 金属板対向時では得られない $L$ の差異が無くなる 周波数が得られた。

(2) リフトオフ $z(\mathrm{~m})$ とコイルの平均直径 $D(\mathrm{~m})$ の正規 化による $L$ の変化を調査した。その結果, $1 \mathrm{kHz}$ の場合は $z, 200 \mathrm{kHz}$ の場合は $D$ の方が $L$ の変化率 に影響を与えると考えられる。

(3) $D$ と金属板の幅 $W(\mathrm{~m})$ の正規化による $L$ の変化を 調査した。その結果, $1 \mathrm{kHz}$ の場合 $D / W$ は約 $1 / 2$, $200 \mathrm{kHz}$ の場合 $D / W$ は約 1 の時に $L$ の変化が最大 となった。これは $1 \mathrm{kHz}$ における非磁性金属板と 異なる結果が得られた。

本報告の結果より磁性金属板判別のための最適コ イルサイズが明らかとなり，コイルサイズの最適化に よって更なる小型化が可能であると考えられる。

今後の課題として，リフトオフやコイルサイズの変 化に対して何故 $L$ が実測結果のように変化するのか明 らかになっておらず, 有限要素法を用いて磁束密度分 布の解析を行い，その要因を検討する必要がある。ま た，コイル抵抗についても正規化を行い，実測值及び 解析值から最適なコイルサイズを検討寸る必要がある。

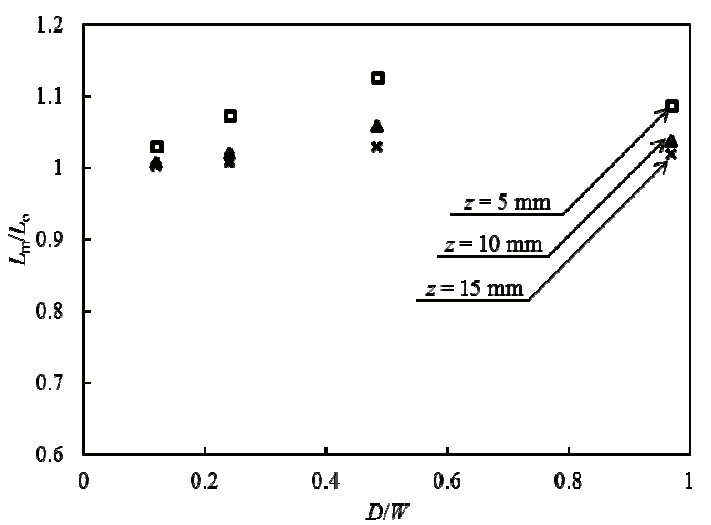

(a) $f=1 \mathrm{kHz}$

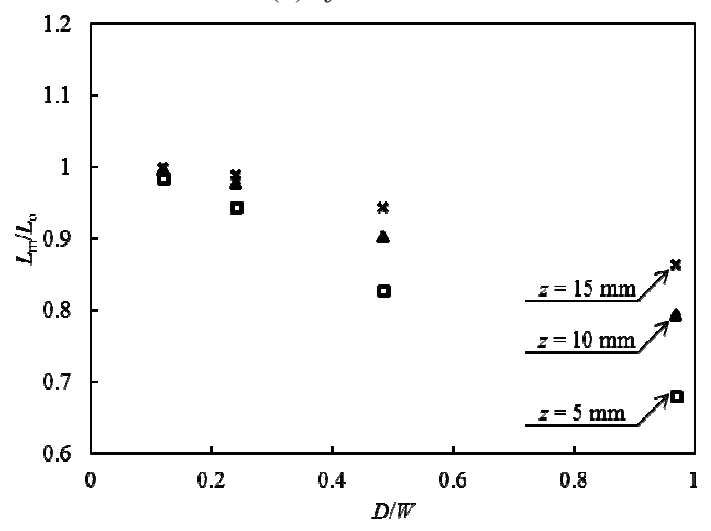

(b) $f=200 \mathrm{kHz}$

Fig. 9 Normalized inductance as a function of normalized diameter, as a parameter of distance between the coil and metal plate.

\section{参考文献}

[1] 日本非破壊委員会, 「非破壊検査便覧」, 日本工業新聞社, p.121, p.360, p.624, 1967.

[2] Shaoni Jiao, Xiaohua Liu, Zhiwei Zeng, "Intensive study of skin effect in eddy current testing with pancake coil, IEEE Transactions on Magnetics, Vol.53, pp.1-7, 2017.

[3] 藤田竜司, 皆方快公, 田代晋久, 脇若弘之, 中村善宏, 松藤宏，齋藤脩平，「ステップ応答法を用いた $\Phi 9, \Phi 18$ コイルによる金属板判別法の検討」，マグネティックス/ リニアドライブ合同研究会, MAG-17-68, LD-17-36, pp.35-40, 2017.

[4] 木村藤一郎, 藤田竜司, 二俣昌樹, 田代晋久, 脇若弘之, 中村善宏，田中伸幸，齋藤脩平，「非磁性金属板判別のた めの空心円形コイルのサイズ検討」, 第 26 回 MAGDA コ ンファレンス講演論文集, 2017.

[5] 自然科学研究機構国立天文台,「理科年表平成 15 年(机上 版)」, 丸善株式会社, p.406, 2003.

[6] 柁川一弘, 海保勝之, 「矩形断面円筒形コイル用自己イン ダクタンス計算式の適用範囲について」, 低温工学, Vol.30, No.7, pp.324-332, 1995. 